\title{
LEXICOGRAPHIC DESCRIPTION OF THEOLINGUISTIC TERMINOLOGY (EXEMPLIFIED BY THE RUSSIAN AND POLISH LANGUAGES)
}

\author{
Aleksander Gadomski \\ Opole University, Opole, Poland
}

\begin{abstract}
The paper deals with the problems of lexicographic description of Russian and Polish theolinguistic terminology. We describe theolinguistics as one of the subdisciplines of linguistics, which main focus is on the reflection of religion in language. We present the most important achievements in the given field at the turn of the $20^{\text {th }}$ and $21^{\text {st }} \mathrm{cc}$., specify the relevant theoretical and applied aspects of contemporary theolinguistic studies. However, it is shown that there is a gap in the modern theolinguistic research - the lack of a comprehensive description of the terminology of Slavonic theolinguistics. An attempt has been made to give a lexicographical description of theolinguistic terminology - a draft dictionary divided into four chapters: alphabetical and thematical lists of Polish-Russian theolinguistic terminology; alphabetical and thematical lists of scholarly works, which were the source of terminology presented in the first two chapters. The analysis and processing of vocabulary and bibliography have been carried out using the classical and modern scholarly methods and the computer technologies. Terminology and bibliography of theolinguistics shall be presented in alphabetical and thematical (ideographical) order.

There is a potentially wide spectrum of fundamental research problems in the field of Slavonic and particularly Russian and Polish theolinguistics. These disciplines can be further developed through the contacts with the leading centers of theolinguistic research in the contemporary world as well as with the help of rising interest of various scholars working in the fields of linguistics, religion, anthropology, etc.

The dictionary can be used not only in scholarly work but also in the process of education.

Key words: lexicography, theolinguistics, terminology, terminology of theolinguistics, Russian language, Polish language, dictionary, dictionary structure.

Citation. Gadomski A. Lexicographic Description of Theoinguistic Terminology (Exemplified by the Russian and Polish Languages). Vestnik Volgogradskogo gosudarstvennogo universiteta. Seriya 2, Yazykoznanie [Science Journal of Volgograd State University. Linguistics], 2018, vol. 17, no. 1, pp. 17-28. (in Russian). DOI: https:// doi.org/10.15688/jvolsu2.2018.1.2
\end{abstract}

УДК $811.161 .1+811.162 .1$ '374

Дата поступления статьи: 30.11.2017

ББК $81.41-4$ Дата принятия статьи: 24.01.2018

\section{ЛЕКСИКОГРАФИЧЕСКОЕ ОПИСАНИЕ ТЕРМИНОЛОГИИ ТЕОЛИНГВИСТИКИ (НА ПРИМЕРЕ РУССКОГО И ПОЛЬСКОГО ЯЗЫКОВ)}

\section{Александр Казимирович Гадомский}

Опольский университет, г. Ополе, Польша

Аннотация. Статья посвящена проблемам лексикографического описания русской и польской теолингвистической терминологии, которое основано на понимании теолингвистики как раздела языкознания, изучающего отражение религии в языке. Охарактеризованы достижения теолингвистики конца XX - начала XXI в., сформулированы ее теоретические и прикладные задачи. Показано, что в современных исследованиях отсутствует комплексное описание терминологии славянской теолингвистики, и предложен проект биб- 
лиографического словаря русско-польской теолингвистической терминологии. Определены теоретические принципы, положенные в основу лексикографирования терминологических единиц, содержание основных этапов работы и критерии отбора терминов. Обработка лексического и библиографического материала осуществляется с использованием классических и современных научных методов, а также с применением компьютерных средств и технологий.

Подробно представлена структура словаря, который состоит из четырех частей: алфавитного и тематического списков терминологии, а также из алфавитного и тематического списков научных работ, которые послужили источниками отбора терминологии.

Выявлены возможности практического применения словаря, а также перспективы славянской, в частности русской и польской теолингвистики, способствующей укреплению связей между ведущими центрами теолингвистических исследований в современном мире и широкому привлечению представителей языковедческих, богословских, религиоведческих, культурологических и других научных направлений к развитию данной области языкознания.

Ключевые слова: лексикография, теолингвистика, терминология, терминология теолингвистики, русский язык, польский язык, словарь, структура словаря.

Цитирование. Гадомский А. К. Лексикографическое описание терминологии теолингвистики (на примере русского и польского языков) // Вестник Волгоградского государственного университета. Серия 2, Языкознание. -2018. - Т. 17, № 1. - C. 17-28. - DOI: https://doi.org/10.15688/jvolsu2.2018.1.2

\section{Теолингвистика: достижения и задачи}

На рубеже XX-XXI вв. активизировались исследования, проводимые на стыке двух наук: теологии и языкознания. Вследствие этого ученые заговорили о таком разделе языкознания, как теолингвистика. Первоначально возникало много вопросов о самом термине, его дефинициях, о направлениях и методах исследований в теолингвистике, о ее статусе (богословие или языкознание) [Гадомский, 2017; Гадомський, Гадомська, 2016; Кончаревић, 2012; Постовалова, 2012а; 2012б; 2016; 2017; Gadomski, 2016; Gadomski, Gadomska, 2014; Kucharska-Dreiß, 2004]. Пытался найти место для теолингвистики между теографией (разделом теологии) и языкознанием и «отец теолингвистики » Д.-П. ван Ноппен [Noppen, 1988].

Итогом наших размышлений о перечисленных проблемах стало следующее определение теолингвистики: «теолингвистика (от греч. theos - Бог и лат. lingua - язык) - это наука, возникшая на стыке языка и религии и исследующая проявления религии, которые закрепились и отразились в языке» [Гадомский, 2004a, с. 167] (см. также: [Гадомский, 20046, с. 34]).

Позднее это определение было дополнено указанием на то, что теолингвистика - это раздел языкознания, который занимается исследованием религиозного языка в узком и широком понимании этого термина [Гадомс- кий, 2007]. Впоследствии анализ истории языкознания позволил нам расширить дефиницию данного термина и предложить ее более полную формулировку:

теолингвистика:

1) раздел языкознания, который возник вследствие взаимодействия языка и религии, отражает первый этап становления языкознания как науки о языке, призванного служить интересам религии;

2) раздел языкознания, который занимается изучением религиозного языка в узком и широком понимании этого термина и исследованием проявлений религии, которые закрепились и отразились в языке [Gadomski, Łapicz, 2008, с. 51].

Перечислим основные характеристики теолингвистики как науки.

Во-первых, теолингвистика - это раздел науки светской, науки наднациональной, надрелигиозной (надконфессиональной), раздел языкознания. Подтверждением этому могут служить серии теолингвистических публикаций с участием ученых из ряда стран, вышедших на протяжении последних 15-20 лет в Англии, Белоруссии, Бельгии, Германии, Польше, России, Сербии, Словакии, Украине.

Во-вторых, теолингвистика делится на общую и частную (христианская лингвистика, китабистика и др.). Общая теолингвистика с учетом многообразия религий и многогранности рассматриваемого языкового материала изучает общие вопросы, такие как де- 
финиция теолингвистики, определение и универсализация базовых понятий, формирование понятийного аппарата (религиозный язык, религиозный дискурс, религиозный стиль, религиозный жанр и др.) и метаязыка, развитие основных направлений теолингвистических исследований и ряд других общих вопросов.

Частная теолингвистика сосредоточена на проявлениях конкретных религий (христианство, ислам, буддизм и др.) и их отражении в конкретных языках.

Сегодня активно развивается именно частная теолингвистика: если первые теоретические исследования, проводимые на Западе во второй половине XX в., были связаны с протестантизмом [Noppen, 1988], то позднее в Восточной Европе и в России объектом исследования стали православие и католицизм. Как правило, на выбор объекта изучения влияют страна проживания, вероисповедание и язык исследователя. Однако на протяжении последних нескольких лет ученые в разных странах независимо от родного языка и вероисповедания все чаще стали обращаться к исламу и его отражению в культурах (и языках) разных народов [Kończak, 2011; Święte księgi..., 2016].

В-третьих, теолингвистика делится на теоретическую и прикладную. Теоретический характер теолингвистики не требует разъяснения. Он подтверждается наличием докторских и кандидатских диссертаций, защищенных в последнее десятилетие в славянских странах, а также многочисленными публикациями теоретического характера. Реализацией прикладного направления в теолингвистике являются не только словари религиозной лексики (одно- и двуязычные [Lewicki, 2002; Markunas, Uczyciel, 1999]), но и разработка методик преподавания различных теолингвистических дисциплин в светских и духовных учебных заведениях.

B-четвертых, теолингвистика развивается и как синхроническая, и как диахроническая. Синхроническая теолингвистика изучает процессы, происходящие в религиозном языке на современном этапе или на определенном историческом отрезке. Следует отметить, что сегодня, в связи с активизацией деятельности Церкви, происходят активные изменения, например, в современном русском языке: в язык проникают новые и возвращаются многие давно забытые слова, происходит возрождение, актуализация их первоначальных значений. Многочисленные метафоры, связанные с религиозными образами, устойчивые обороты стали все чаще звучать в разговорной речи. В связи с канонизацией новых святых создаются на церковнославянском языке их жития [Ицкович, 2015]. Происходит своеобразное оживление мертвого языка. Преподавание Закона Божьего в воскресных школах, контакты представителей различных религий, язык религиозных СМИ и многие другие актуальные проблемы становятся объектом исследования синхронической теолингвистики.

Диахроническая теолингвистика изучает динамику религиозного языка во времени и представлена исследованиями в области старославянского / церковнославянского языков, истории славянских языков, исследованиями, проводимыми в области этимологии.

В-пятых, предмет исследования теолингвистики составляют проявления религии, которые отразились и закрепились в языке, а также язык как форма религии в корреляциях «религия - содержание, язык - форма», как способ отражения, сохранения и передачи религиозного содержания. Здесь речь идет и о языке светском (не религиозном, не сакральном, а профанном), который на всех языковых ярусах изобилует богатейшим материалом, заимствованным из религиозного языка.

Цель теолингвистики состоит в изучении этих проявлений, ее достижение предполагает последовательное решение задач, связанных с:

- выбором материала из соответствующих источников: текстов (в данном случае текст мы понимаем в широком смысле этого слова), речи (устной и письменной), интернети других источников;

- дифференциацией, интеграцией, систематизацией полученного материала и обработкой его с использованием теолингвистических методов и методов смежных наук [Gadomski, Łapicz, 2008, c. 51-52].

Теолингвистика, по нашему мнению, должна решать не только сугубо научные задачи, но и прагматические, прикладные: дидактические, образовательные, социальные, культурные, этические и многие другие. Их реше- 
ние должно способствовать формированию «картины мира» человека новой эры - человека образованного, терпимого, толерантного, допускающего, что в системе научных взглядов могут иметь место не только материалистические теории. Язык - одна из базовых составляющих любой религии. Именно через язык, в первую очередь, происходит познание многих «невидимых глазу» явлений, понятий. Сегодня, пожалуй, не найдется ни одного ученого, который мог бы с уверенностью ответить на вопросы «есть ли Бог?», «какой он?» и ряд других. Ответ нужно искать в самом языке, в тех картинах и образах, которые он создает, - другими словами, в языковой картине мира, фрагментом которой является «языковая картина мира религии», «языковая картина мира Sacrum», которая противопоставлена «языковой картине мира Profanum». В повседневной жизни в решении вопросов, связанных с религией, язык является самым авторитетным источником. По мнению А. Новицкого, с языком в свое время не спорили даже атеисты, утверждая, что Бог существует только в языке [Nowicki, 1964; цит. по: Makuchowska, 1998, s. 14].

Эволюция теолингвистики на протяжении последней четверти века привела к ответу на ряд вопросов и к решению научных проблем в рамках названного раздела языкознания. Многие теолингвистичекие гипотезы нашли свое подтверждение. Сегодня термин «теолингвистика» функционирует в работах ученых Англии, Белоруссии, Бельгии, Германии, Польши, России, Сербии, Словакии, Украины.

Именно теолингвистика на протяжении более чем пятнадцати лет является объектом наших исследований. Наиболее полную информацию о теолингвистических исследованиях в целом, о славянской теолингвистике (прежде всего, польской, русской, сербской и украинской), как и о работах автора статьи, можно найти в недавно изданной книге «Теолингвистические исследования в славянском языкознании» [Гадомский, 2017].

Хотелось бы отметить, что в последние годы право теолингвистики быть разделом языкознания практически не оспаривается. Определены основные направления теолингвистических исследований. Сформировался богатый корпус теолингвистических работ теоретического и прикладного характера, о чем свидетельствует обширная библиография.

Кроме того, теолингвистика сегодня это не только раздел языкознания, направление научных исследований, но и учебная дисциплина, которая преподается в вузах России (И.В. Бугаева, А.К. Гадомский, В.И. Постовалова), Сербии (К. Кончаревич, Р. Левушкина-Баич), Польши (А.К. Гадомский, М. Макуховска, В. Хлебда) [Кончаревић, 2015; Хрестоматия теолингвистики, 2008 и др.]. Разработаны учебные программы теолингвистических дисциплин [Гадомский, 2015].

\section{Актуальность \\ лекси кографического описания \\ терминологии теолингвистики}

Вследствие развития теолингвистики постоянно пополняется и развивается ее терминологический аппарат. Однако он до сих пор не упорядочен, не систематизирован, комплексно не описан. Все это свидетельствует только о том, что нужен словарь (энциклопедия, справочник) терминологии теолингвистики, который до сих пор не создан.

Актуальность лексикографической фиксации представления терминологии рассматриваемой предметной области обусловлена и тем, что сам термин «теолингвистика» не представлен надлежащим образом в словарях лингвистических терминов: он еще не вошел, например, ни в русскоязычные, ни в польскоязычные словари лингвистических терминов, справочники, энциклопедии (за исключением переводных). Словарную статью «теолингвистика» нам удалось найти только в одной англоязычной энциклопедии и ее переводных вариантах [Crystal, 1987, p. 412; Crystal, 1995, S. 412]. Отсутствие такого словаря затрудняет как проведение дальнейших исследований в названной области, так и преподавание теолингвистики. Сам по себе этот факт свидетельствует о том, что в современном языкознании, и прежде всего в современной славянской теолингвистике, как в отечественной, так и в зарубежной, еще достаточно много «лакун», в том числе и терминологических. Это делает все исследования в области терминологии славянской теолингвистики и ее лексикографического описания особенно актуальными. 
В настоящее время наши теолингвистические исследования связаны с отбором теолингвистической терминологии из авторитетных научных источников (монографий, словарей, энциклопедий, диссертаций, научных статей и т. п.), с ее обработкой и упорядочением: систематизацией в алфавитном и тематическом порядке.

На протяжении ряда лет нами ведется работа по подготовке «Учебного библиографического словаря русско-польской терминологии теолингвистики». На мысль создания «библиографического словаря» натолкнул нас «Библиографический словарь общего и польского языкознания» польского лингвиста Яна Вавжинчика [Wawrzyńczyk, 2005].

Почему именно русско-польский? Развитие славянской теолингвистики последних пятнадцати лет связано с польской, которая стала своеобразным средством объединения западной и славянской теолингвистики. Авторы многих современных работ в данной области, изданных на русском, украинском, сербском языках, часто ссылаются на работы польских исследователей. Целый ряд теолингвистических понятий, постулатов, тезисов, определений уже сформулированы на русском и польском языках. Отчасти эти описания дополняют друг друга, а в ряде случаев этого не происходит. И поэтому возникла необходимость обобщенного представления теолингвистических терминов и заполнения «лакун», что должно способствовать решению не только частных, но и общих проблем теолингвистики. По нашему мнению, это должно повлечь за собой также систематизацию исследований в названной области. Издание такого словаря должно положительно повлиять на развитие различных направлений теолингвистики.

\section{Этапы работы}

1. Прежде всего составляется максимально полный библиографический список теолингвистических работ на русском и польском языках. В этом направлении ведется активная работа [Гадомский, Кончаревич, 2014; Мова і релігія..., 2016; Петровић, 2015; Bibliografia..., 2007].

2. Создается корпус текстов теолингвистических и связанных с ними научных иссле- дований на русском и польском языках: монографий, диссертаций, статей, словарей и других научных работ. Прежде всего: польская серия «Teolingwistyka»; публикации издательства «Biblos» [Pisownia..., 2011; Polszczyzna biblijna..., 2009 и др.]; «Język religijny dawniej i dziś», издаваемая в Университете Адама Мицкевича в г. Познань (Польша) [2004; 2005; 2007; 2008; 2009]; «Хрестоматия теолингвистики» (г. Симферополь, Крым) [2008]; «Теолингвистика. Зборник научних радова» [2012], изданный в Белградском университете, и «Теолингвистичка проучавања словенских језика», изданный Отделением языка и литературы Сербской академии наук и искусств (г. Белград, Республика Сербия) [2013]; трехтомник «Święte księgi judaizmu, chreścijaństwa $\mathrm{i}$ isłamu $\mathrm{w}$ słowiańskim kręgu kulturowym», изданный в Университете Николая Коперника (г. Торунь, Польша) [2016], и ряд других.

3. Из корпуса текстов, из авторитетных источников отбирается польская и русская терминология [Карасик, 1999; Постовалова, 2012а; 2012б; 2016; 2017; Прохватилова, 1999; Beńkowska, 2002; Kończak, 2011 и др.]. При этом термины не переводятся, а сопоставляются и объединяются в переводные пары. Примером применения такой методики может служить «Идиоматикон», подготовленный коллективом Института славистики Опольского университета в Польше [Polsko-rosyjski słownik..., 2014].

4. Отдельно фиксируются случаи, когда у терминов одного языка не обнаруживается соответствий в другом языке (то есть особое внимание уделяется лексическим единицым, у которых нет переводных пар).

5. По мере возможности каждый термин сопровождается списком литературы, чтобы пользователи словаря, работая с терминологией, могли иметь доступ к информации об источниках материала, в которых описываются те или иные проблемы.

6. Формируется алфавитный список терминов (переводных пар) с «привязанной» к ним библиографической информацией. Расположение материала в алфавитном порядке позволяет быстро находить нужный термин в представленном списке и получать информацию об источниках, в которых он употребляется. Каждый термин в алфавитном списке снаб- 
жается «адресом» в тематическом (идеографическом) списке, чтобы его без труда можно было там отыскать.

7. Термины (переводные пары) представляются в тематическом (идеографическом) порядке. Подобная подача материала позволяет получать информацию не только об отдельных терминах, но и о терминологической системе, реализуемой в теолингвистических исследованиях в целом, о состоянии изученности тех или иных проблем теолингвистики.

8. Структурируется библиография теолингвистических работ в алфавитном и тематическом (идеографическом) порядке.

\section{Критерии отбора материала}

В процессе выработки критериев отбора лексикографируемого материала возникли вопросы о том, какой терминологией следует пользоваться, целесообразно ли «изобретать» новую терминологию теолингвистики, что можно считать источником терминологии теолингвистики.

Подобно тому, как каждый раздел науки зарождается и развивается до определенного момента в границах других наук, зарождается и развивается терминология.

В поисках ответов на поставленные вопросы мы считаем необходимым руководствоваться следующими принципами.

1. «Изобретать» новую терминологию нет необходимости (так считает и польская исследовательница Д. Беньковска: [Bieńkowska, 2002]), по возможности следует использовать уже существующую лингвистическую терминологию и терминологию наук, тесно связанных с теолингвистикой. Если возникает проблема выбора одного из конкурирующих и равноценных терминов, а термин уже существует и распространен, предпочтение следует отдавать тому, который более распространен. Способом проверки частотности терминов могут служить, например, поисковые системы «Яндекс», «Google» и др.

2. Учет интернационального характера терминологии позволяет использовать в качестве ее источника написанные на русском и польском языках энциклопедии, справочники, терминологические и лингвистические словари, труды лингвистов, теологов, философов и других ученых, разрабатывающих проблемы теолингвистики в том или ином аспекте.

Поэтому наш словарь представляет собой попытку объединения уже функционирующей терминологии, преимущественно русской и польской, которая может считаться терминологией теолингвистики. Терминология, которой может оперировать или уже оперирует теолингвистика, была собрана и систематизирована с учетом перечисленных выше принципов.

В основном в словарь помещались термины, существование которых подтверждено «документально», то есть те, которые уже зафиксированы в научной литературе, что подкреплено ссылками на соответствующие источники, в которых эта терминология употребляется. Часть слов вошла в словарь без русских или польских аналогов. Это значит, что на данном этапе исследования названные термины нами не были обнаружены.

В настоящее время словарь включает более 350 переводных пар русских и польских теолингвистических терминов.

Порядок работы помог сформировать структуру словаря.

\section{Структура словаря}

Словарь предположительно должен состоять из четырех основных частей, материал в некоторых из них предполагается структурировать по разделам.

I. Русско-польская терминология теолингвистики. Алфавитная часть.

II. Русско-польская терминология теолингвистики. Тематическая (идеографическая) часть.

1. Теолингвистика и ее разделы

1.1. Общие понятия теолингвистики

1.2. Разделы теолингвистики, связанные с христианскими религиями

1.3. Разделы теолингвистики, связанные с нехристианскими религиями

2. Религиозный язык и его функции

2.1. Религиозный язык

2.2. Функции религиозного языка

3. Подходы к изучению религиозного языка

3.1. Нелингвистические подходы к изучению религиозного языка 
А.К. Гадомский. Лексикографическое описание терминологии теолингвистики

3.1.1. Философский подход к изучению религиозного языка

3.1.2. Теологический (богословский) подход к изучению религиозного языка

3.1.2.1. Богослужебные книги

3.1.2.1.1. Христианские богослужебные книги

3.1.2.1.2. Нехристианские богослужебные книги

3.1.2.2. Разделы теологии

3.1.3. Религиоведческий подход к изучению религиозного языка

3.1.4. Исторический подход к изучению религиозного языка

3.1.5. Семиотический подход к изучению религиозного языка

3.1.6. Аксиологический подход к изучению религиозного языка

3.1.7. Литературоведческий подход к изучению религиозного языка

3.1.8. Дидактический поход к изучению религиозного языка

3.2. Лингвистические подходы к изучению религиозного языка

3.2.1. Подход к изучению религиозного языка как фрагменту «языковой картины мира»

3.2.2. Кодовый подход к изучению религиозного языка (как системы систем - уровней (ярусов))

3.2.2.1. Фонетика религиозного языка

3.2.2.2. Алфавит, графика, орфография религиозного языка

3.2.2.3. Лексикология религиозного языка

3.2.2.3.1. Религиозная лексика

3.2.2.3.1.1. Этимология. Заимствования

3.2.2.3.1.2. Ономастика религиозного языка

3.2.2.3.1.3. Терминология религиозного языка

3.2.2.3.2. Фразеология религиозного языка

3.2.2.3.3. Религиозная лексикография

3.2.2.3.3.1. Словари

3.2.2.3.3.2. Способы толкования в словарях

3.2.2.4. Словообразование религиозного языка

3.2.2.5. Грамматика религиозного языка

3.2.2.5.1. Морфология религиозного языка

3.2.2.5.2. Синтаксис религиозного языка

3.2.2.6. Религиозный текст

3.2.3. Стилистический подход к изучению религиозного языка
3.2.3.1. Религиозный стиль

3.2.3.2. Стили религиозного языка

3.2.3.3. Подстили религиозного стиля

3.2.4. Жанровый (генологический) подход к изучению религиозного языка

3.2.4.1. Агиографическая литература

3.2.4.2. Переводы религиозных текстов

3.2.4.2.1. Переводы текстов христианских религий

3.2.4.2.2. Переводы текстов нехристианских религий

3.2.4.3. Духовное (епископское) послание

3.2.4.4. Исповедь

3.2.4.5. Молитва

3.2.4.6. Папская энциклика

3.2.4.7. Письменная инструкция

3.2.4.8. Притча

3.2.4.9. Приходское объявление

3.2.4.10. Проповедь

3.2.4.11. Пророчество и другие профетические жанры

3.2.4.12. Религиозные песнопения и гимны

3.2.4.13. Свидетельство

3.2.4.14. Эортологическая литература

3.2.5. Дискурсивный подход к изучению религиозного языка

3.2.6. Коммуникативный поход к изучению религиозного языка

III. Русско-польская библиография теолингвистики. (Алфавитная часть).

В данном разделе должны быть систематизированы в алфавитном порядке источники выбора русско-польской теолингвистической терминологии, представленной в первых двух частях словаря.

IV. Русско-польская библиография теолингвистики. Тематическая (идеографическая) часть.

В данном разделе должны быть приведены в тематическом (идеографическом) порядке источники выбора русско-польской терминологии теолингвистики, представленной в первых двух частях словаря.

\section{Предлагаемые методы и технологии}

В процессе подготовки словаря применяются различные методы и технологии, богатым арсеналом которых располагает современная лексикография и которые можно условно разделить на несколько групп. 
1. Классические - с использованием бумажных носителей.

2. Современные, модернизированные с использованием компьютерных программ и технологий.

3. Методы корпусной лексикографии, которая интегрирует «классические» и компьютерные методы и приемы.

Методы каждой из названных групп дополняют друг друга и, в принципе, не могут существовать друг без друга. Следует также отметить, что современные технологии позволяют создать интерактивный словарь с гиперссылками и с возможностью постоянного пополнения или периодического его обновления. Однако это, скорее, дальняя перспектива.

\section{Практическое применение словаря}

Словарь может быть использован не только в научно-исследовательской, но и в педагогической работе. Он должен способствовать систематизации и упорядочению теолингвистических исследований, а также служить подспорьем в преподавании в светских и духовных учебных заведениях предметов, затрагивающих проблемы взаимодействия языка и религии.

Введение курса «Теолингвистика» в программу обучения филологов, богословов, религиоведов продиктовано наметившимся в Польше, России, Сербии, Украине и других странах на рубеже XX-XXI вв. религиозным возрождением; межконфессиональными встречами представителей различных стран; поликонфессиональностью многих регионов, а также особенностями религиозной культуры, спецификой литературы и языка, вобравшими в себя многое из религиозной истории.

Славянская, в частности русская и польская, теолингвистика, рассматривая фундаментальные проблемы, имеет широкий спектр практического применения. В перспективе она может способствовать укреплению связей с ведущими центрами теолингвистических исследований в современном мире и привлечению представителей языковедческих, богословских, религиоведческих, культурологических и других научных направлений к развитию данной области языкознания.

\section{СПИСОК ЛИТЕРАТУРЫ}

Гадомский А. К., 2004а. О лакунах в системе лингвистической науки: проблема взаимодействия языка и религии // Культура народов Причерноморья. Т. 1, № 49. С. 164-167.

Гадомский А. К., 2004б. Семантико-прагматические проблемы теолингвистики // Науковий вісник Луганського національного педагогічного університету. № 12 (80). С. 33-38.

Гадомский А. К., 2007. Религиозный язык - теолингвистика - языкознание // Ученые записки Таврического национального университета им. В.И. Вернадского. Т. 20 (59), № 1. С. 287-293.

Гадомский А. К., 2015. К вопросу о преподавании теолингвистических дисциплин в светских и богословских учебных заведениях // Русский язык как инославянский. Вып. VII: Современное изучение русского языка и русской культуры в инославянской среде. Белград : Славистическое общество Сербии. С. 78-95.

Гадомский А. К., 2017. Теолингвистические исследования в славянском языкознании. Симферополь : Форма. 320 c.

Гадомский А. К., Кончаревич К., 2014. Преглед теолингвистичких испитивања у Русији, Украјини и Пољској (грађа за библиографију) // Српска теологија у двадесетом веку: истраживачки проблеми и резултати / уред. Б. Шијаковић. Београд : Православни богословски факултет. Књ. 16. С. 151-178.

Гадомський О., Гадомська Г., 2016. Сучасний стан теолінгвістичних досліджень в пострадянських країнах (на прикладі Польщі, Росії, Сербії та Україні) // Święte księgi judaizmu, chreścijaństwa $\mathrm{i}$ isłamu w słowiańskim kręgu kulturowym. Prace dedukowani Profesorowi Czesławowi Łapiczowi / red. M. Krajewska, J. Kulwicka-Kamińska, A. Szulc. Torun : Wydawnictwo UMK w Toruniu. T. 3. C. 43-62.

Ицкович Т. В., 2015. Категориально-текстовая специфика современной православной проповеди. Екатеринбург : Ажур. 150 с.

Карасик В. И., 1999. Религиозный дискурс // Языковая личность: проблемы лингвокультурологии и функциональной семантики : сб. науч. тр. Волгоград : Перемена. С. 5-19.

Кончаревић К., 2012. Источноевропска теолингвистика данас: општа лингвистика, славистика, стране филологије // Српска теологија у двадесетом веку: истраживачки проблеми и резултати. Књ. 10. Зборник радова научног скупа (ПБФ Београд, 23. децембар 2011) / прир. Б. Шијаковић. Београд : Православни богословски факултет. С. 145-171. 
Кончаревић К., 2015. Поглед у теолингвистику. Београд : Православни богословски факултет. $364 \mathrm{c}$.

Мова і релігія: бібліографічний покажчик, 2016. Укл. М. Скаб. Чернівці : Родовід. 344 с.

Петровић С., 2015. Библиографија Расправа и дела из теолингвистике која су изашла у Србији, Црној Гори и Републици Српској ОД 2000. до 2015. Године // Српска теологија у двадесетом веку: истраживачки проблеми и резултати / прир. Б. Шијаковић. Београд : Православни богословски факултет. Књ. 18. С. 116-147.

Постовалова В. И., 2012а. Религиозные концепты в теолингвистическом представлении // Теолингвистика: међународни тематски зборник радова / прир. А. К. Гадомски, К. Кончаревић. Београд : Универзитет, Православни богословски факултет, Институт за теолошка истраживања. С. 143-152.

Постовалова В. И., 2012б. Теолингвистика в современном гуманитарном познании: истоки, основные идеи и направления // «Magister Dixit» - научно-педагогический журнал Bocточной Сибири. № 4 (12). С. 54-101.

Постовалова В. И., 2016. Наука о языке в свете идеала цельного знания: в поисках интегральных парадигм. М. : ЛЕНАНД. 272 с. (История лингвофилософской мысли).

Постовалова В. И., 2017. Язык и миропонимание. Опыт лингвофилософской интерпретации (лингвофилософские очерки). М. : ЛЕНАНД, 2017. 312 с. (История лингвофилософской мысли).

Прохватилова О. А., 1999. Православная проповедь и молитва как феномен современной звучащей речи. Волгоград : Издательство ВолГУ. $364 \mathrm{c}$.

Теолингвистика : зборник научних радова, 2012. Прир. А. К. Гадомски, К. Кончаревић. Београд : Православни богословски факултет Институт за теолошка истраживања. 496 с.

Теолингвистичка проучавања словенских језика, 2013. Прир. Ј. Грковић-Мејџор, К. Кончаревић. Београд : Српска акдемија наука и уметности. 536 с.

Хрестоматия теолингвистики \| Chrestomatia teolingwistyki, 2008. Ред. А. К. Гадомский, Ч. Лапич. Симферополь : Универсум. 352 с.

Bibliografia języka religijnego (1945-2005), 2007. Zb. i opr. M. Makuchowska. Tarnów : Biblós. $192 \mathrm{~s}$.

Bieńkowska D., 2002. Polski styl biblijny. Łódź : Archidiecezjalne Wydawnictwo Łódzkie. $160 \mathrm{~s}$.

Crystal D., 1995. Die Cambridge-Enzyklopädie der Sprache, Übers. und Bearb. Der dt Ausg. Von Stefan Röhrich, Campus. Frankfurt a.M. ; New York [оригинал: D. Crystal. The Cambridge
Encyclopedia of Language. Cambridge ; New York; Melbourne : Cambridge University Press, 1987]. $488 \mathrm{~S}$.

Gadomski A., 2016. Основные направления теолингвистических исследований в польском и русском языкознании // Nauka w Polsce i Rosji - miejsca wspólne, miejsca różne (obszar humanistyki) / red. M. Dąbrowska, P. Głuszkowski. Warszawa : Zakład Graficzny Uniwersytetu Warszawskiego. S. 253-262.

Gadomski A., Gadomska H., 2014. Teolingwistyka polska w kontekście teolingwistyki słowiańskiej // Prace naukowe Akademii im. Jana Długosza w Częstochowie. Z. 10: Językoznawstwo Częstochowa. S. 6-23.

Gadomski A., Łapicz Cz., 2008. Teolingwistyka: historia, stan współczesny, perspektywy // Xpeстоматия теолингвистики || Chrestomatia teolingwistyki / ред. А. К. Гадомский, Ч. Лапич. Симферополь : Универсум. С. 33-60.

Język religijny dawniej i dziś, 2004. Red. S. Mikołajczak, T. Więcławski. Poznań : Poznańskie studia polonistyczne. T. I. $448 \mathrm{~s}$.

Język religijny dawniej i dziś, 2005. Red. S. Mikołajczak, T. Więcławski. Poznań : Poznańskie studia polonistyczne. T. II. $538 \mathrm{~s}$.

Język religijny dawniej i dziś, 2007. Red. S. Mikołajczak, T. Więcławski. Poznań : Poznańskie studia polonistyczne. T. III. $606 \mathrm{~s}$.

Język religijny dawniej i dziśs (w kontekście teologicznym i kulturowym), 2008. Red. ks. P. Bortkiewicz, S. Mikołajczak, M. Rybka. Poznań : Poznańskie studia polonistyczne. T. IV. $438 \mathrm{~s}$.

Język religijny dawniej i dziś (w kontekście teologicznym i kulturowym), 2009. Red. ks. P. Bortkiewicz, S. Mikołajczak, M. Rybka. Poznań : Poznańskie studia polonistyczne. T. V. $520 \mathrm{~s}$.

Kończak I., 2011. Kształtowanie się rosyjskiej terminologii islamistycznej na podstawie czterech rosyjskich przekładów Koranu. Łódż : Ibidem. $278 \mathrm{~s}$.

Kucharska-Drei $\beta$ E., 2004. Teolingwistyka - próba popularyzacji terminu // Język religijny dawniej i dziś / red. S. Mikołajczak, T. Więcławskim. T. I. Poznań : Poznańskie studia polonistyczne. S. 23-30.

Lewicki R., 2002. Chrześcijaństwo. Słownik rosyjskopolski. Warszawa : Pax. 367 s.

Makuchowska M., 1998. Modlitwa jako gatunek języka religijnego. Opole : UO. $127 \mathrm{~s}$.

Markunas A., Uczyciel T., 1999. Leksykon Chrześcijaństwa rosyjsko-polski i polskorosyjski. Poznań : UAM. 370 s.

Noppen J.-P. van., 1988. Erinnern, um Neues zu sagen. Die Bedeutung der Metapher für die religiöse Sprache. Frankfurt am Main : Athenäum Verlag. $320 \mathrm{p}$. 
Nowicki A., 1964. Ateizm. Warszawa : Wydawnictwo Iskry. $141 \mathrm{~s}$.

Pisownia słownictwa religijnego, 2011. Red. R. Przybylska, ks. W. Przyczyna. Tarnów : Biblos. $132 \mathrm{~s}$.

Polsko-rosyjski słownik par przekładowych. Tom zbiorczy «Podręcznego idiomatykonu polskorosyjskiego» (z. 1-5), 2014. Red. W. Chlebda. Opole : Wydawnictwo Uniwersytetu Opolskiego. $756 \mathrm{~s}$.

Polszczyzna biblijna - między tradycją a współczesnością, 2009. Red. ks. W. Przyczyna, S. Koziara. Tarnów : Bibłos. T. I. 335 s.

Święte księgi judaizmu, chreścijaństwa i isłamu w słowiańskim kręgu kulturowym. Prace dedukowani Profesorowi Czesławowi Łapiczowi, 2016. Red. M. Krajewskia, J. Kulwicka-Kamińska, A. Szulc. Torun : Wydawnictwo UMK w Toruniu. T. 1-3 (T. 1.286 s., T. 2.246 s., T. 3.300 s.).

Wawrzyńczyk J., 2005. Słownik bibliograficzny językoznawstwa ogólnego i polonistycznego. Warszawa : Dialog. 406 s.

\section{REFERENCES}

Gadomskiy A.K., 2004a. About gaps in linguistics: the problem of the interaction of language and religion. Kultura narodov Prichernomorya, vol. 1, no. 49, pp. 164-167.

Gadomskiy A.K., 2004b. Semantic and pragmatic problems of theolinguistics. Naukovij visnik Luganskogo natsionalnogo pedagogichnogo universitetu [Scientific Herald of Lugansk National Pedagogical University], no. 12 (80), pp. 33-38.

Gadomskiy A.K., 2007. Religious language theolinguistics - linguistics. Uchenye zapiski Tavricheskogo natsionalnogo universiteta im. V.I. Vernadskogo [Scientific Notes of Taurida National V.I. Vernadsky University], vol. 20 (59), no. 1, pp. 287-293.

Gadomskiy A.K., 2015. On teaching theolinguistic disciplines in secular and theological educational institutions. Russkiy yazyk kak inoslavyanskiy. Vyp. VII: Sovremennoe izuchenie russkogo yazyka $i$ russkoy kultury $v$ inoslavyanskoy srede. Belgrad, Slavisticheskoe obshchestvo Serbii, pp. 78-95.

GadomskiyA.K., 2017. Theolinguistic studies in Slavic linguistics. Simferopol, Forma Publ. 320 p.

Gadomskiy A.K., Koncharevich K., 2014. Overview of the theolinguistic tests in Russia, Ukraine and Poland (bibliography)]. Shijakovih B., ed. Srpska teologija u dvadesetom veku: Istrazhivachki problemi i rezultati [Serbian
Theology in the $20^{\text {th }}$ Century: Research Problems and Results]. Beograd, Pravoslavni bogoslovski fakultet, vol. 16, pp. 151-178.

Gadomskiy O., Gadomska G., 2016. The current state of theological studies in the post-Soviet countries (the case study of Poland, Russia, Serbia and Ukraine). Krajewska M., Kulwicka-Kamicska J., Szulc A., eds. Święte księgi judaizmu, chreścijaństwa i isłamu $w$ stowiańskim kręgu kulturowym. Prace dedukowani Profesorowi Czestawowi Lapiczowi [Sacred Books of Judaism, Charisma and the Idol in the Slavic Cultural Circle. Works by Professor Czesiaw Japicz]. Toruń, Wydawnictwo UMK w Toruniu, vol. 3, pp. 43-62.

Itskovich T.V., 2015. Categorical and Textual Specificity of the Modern Orthodox Sermon. Ekaterinburg, Azhur Publ. 150 p.

Karasik V.I., 1999. Religious Discourse. Yazykovaya lichnost: problemy lingvokulturologii $i$ funktsionalnoy semantiki: sb. nauch. tr. Volgograd, Peremena Publ., pp. 5-19.

Koncharevih K., 2012. Historical-European theology linguistics, Slavic studies, country philology. Shijakovih B., ed. Srpska teologija u dvadesetom veku: Istrazhivachki problemi $i$ rezultati [Serbian Theology in the $20^{\text {th }}$ Century: Research Problems and Results]. Beograd, Pravoslavni bogoslovski fakultet, vol. 10, pp. 145-171.

Koncharevih K., 2015. A look at the teolinguistics. Beograd, Pravoslavni bogoslovski fakultet. $364 \mathrm{p}$.

Skab M., ed. 2016. Language and religion: a bibliographic index. Chernivci, Vidavnichij Dim "Rodovid". 344 p.

Petrovih S., 2015. A bibliography of debates and works from theology, which went to Serbia, Montenegro and the Republic of Serbia in 2000 to 2015. Shijakovih B., ed. Srpska teologija u dvadesetom veku: Istrazhivachki problemi $i$ rezultati [Serbian Theology in the $20^{\text {th }}$ Century: Research Problems and Results]. Beograd, Pravoslavni bogoslovski fakultet, vol. 18, pp. 116-147.

Postovalova V.I., 2012a. Religious concepts in the theolinguistic view. Gadomski A.K., Koncharevih K., eds. Teolingvistika: meちunarodni tematski zbornik radova. Beograd, Pravoslavni bogoslovski fakultet, pp. 143-152.

Postovalova V.I., 2012b. Theolinguistics in modern humanities: origins, basic ideas and directions. «Magister Dixit» - nauchno-pedagogicheskiy zhurnal Vostochnoy Sibiri, no. 4 (12), pp. 54-101.

Postovalova V.I., 2016. Linguistics in the light of the ideal of integral knowledge: in search of 
integral paradigms. Moscow, LENAND Publ. 272 p. (History of linguophilosophical thought).

Postovalova V.I., 2017. Language and worldview. Experience of linguophilosophical interpretation (inguophilosophical essays). Moscow, LENAND Publ. 312 p. (History of linguophilosophical thought).

Prokhvatilova O.A., 1999. Orthodox sermon and prayer as a phenomenon of modern sounding speech: Monograph. Volgograd, Izd-vo VolGU. $364 \mathrm{p}$.

Gadomski A.K., Koncharevih K., eds. 2012. Theolinguistics. Collection of academic papers. Beograd, Pravoslavni bogoslovski fakultet. 496 p.

Grkovih-Mejџor J., Konchareviћ K., eds., 2013. Theolinguistic study of Slovene languages. Beograd, Srpska akdemija nauka i umetnosti. 536 p.

Gadomskiy A.K., Lapich Ch., eds. 2008. Anthology of theolinguistics. Simferopol, Universum Publ. $352 \mathrm{p}$.

Makuchowska M., ed., 2007. Bibliography of religious language (1945-2005). Tarnyw, Biblys. 192 p.

Bieńkowska D., 2002. Polish biblical style. Łódź, Archidiecezjalne Wydawnictwo Łódzki. 160 p.

Crystal D., 1987. The Cambridge Encyclopedia of Language. Cambridge University Press, Cambridge-New York-Melbourne. 488 p.

Gadomski A., 2016. The main directions of theolinguistic research in Polish and Russian linguistics. Dąbrowska M., Głuszkowski P., eds. Nauka w Polsce i Rosji - miejsca wspólne, miejsca różne (obszar humanistyki) [Science in Poland and Russia - common places, different places (area of the humanities)]. Warszawa, Zakład Graficzny UW, pp. 253-262.

Gadomski A., Gadomska H., 2014. Polish theolinguistics in the context of Slavonic theology. Prace naukowe Akademii im. Jana Dlugosza w Częstochowie [Scientific Work of the Academy Jan Długosz in Częstochowa]. Częstochowa, no. 10 , pp. 6-23.

Gadomski A., Łapicz Cz., 2008. Teolinguistics: history, contemporary state, perspectives. Lapich Ch., Gadomskiy A.K., eds. Chrestomatia teolingwistyki [Chrestomatia of theolinguistics]. Simferopol, Universum Publ., pp. 33-60.

Mikołajczak S., Więcławski T., eds. 2004. Religious language in the past and today. Poznań, Poznańskie studia polonistyczne, vol. 1. 448 p.

Mikołajczak S., Więcławski T., eds. 2005. Religious language in the past and today. Poznań, Poznańskie studia polonistyczne, vol. 2. 538 p.
Mikołajczak S., Więcławski T., eds. 2007. Religious language in the past and today. Poznań, Poznańskie studia polonistyczne, vol. 3. 606 p.

Bortkiewicz P., Mikołajczak S., Rybka M., 2008. Religious language in the past and today (in the theological and cultural context). Poznań, Poznańskie studia polonistyczne, vol. 4. 438 p.

Bortkiewicz P., Mikołajczak S., Rybka M., 2009. Religious language in the past and today (in the theological and cultural context). Poznań, Poznańskie studia polonistyczne, vol. 5. 520 p.

Kończak I., 2011. The formation of Russian Islamist terminology based on four Russian translations of the Koran. Łódż, Ibidem. 278 p.

Kucharska-Drei $\beta$ E., 2004. Teolinguistics - an attempt to popularize the term]. Mikołajczak S., T. Więcławskim T., eds. Język religijny dawniej $i d z i s ́$ [Religious language in the past and today]. Poznań, Poznańskie studia polonistyczne, vol. 1, pp. 23-30.

Lewicki R., 2002. Christianity. Russian-Polish dictionary. Warszawa, Pax. 367 p.

Makuchowska M., 1998. Prayer as a species of religious language. Opole, UO, 1998. 127 p.

Markunas A., Uczyciel T., 1999. The lexicon of Christian-Polish and Polish-Russian Christianity. Poznań, UAM. 370 p.

Noppen J.-P. van, 1988. Remember to say something new. The meaning of the metaphor for the religious language. Frankfurt, Athenäum Verlag. 320 p.

Nowicki A., 1964. Language in religion. Nowicki A., ed. Ateizm [Atheism]. Warszawa, Iskry. 141 p.

Przybylska R., Przyczyna W., 2011. Spelling of religious vocabulary. Tarnów, Biblos. $132 \mathrm{p}$.

Chlebda W., ed. 2014. Polish-Russian dictionary of translation pairs. Collective volume of the "Polish-Russian handy idioms". Opole, Wydawnictwo Uniwersytetu Opolskiego, vol. 1-5. $756 \mathrm{p}$.

Przyczyna W., Koziaraed S., eds. 2009. Biblical Polish - between tradition and modernity. Tarnów, Bibłos, vol. 1. 335 p.

Krajewska M., Kulwickiej-Kamińska J., Szulc A., eds. 2016. Sacred books of Judaism, charisma and the idol in the Slavic cultural circle. Prace dedukowane Profesorowi Czestawowi Łapiczowi. Toruń, Wydawnictwo UMK w Toruniu, vol.1-3; (vol. 1. 286 p.; vol. 2. 246 p.; vol. 3.300 p.)

Wawrzyńczyk J., 2005. Bibliographic dictionary of general and Polish linguistics. Warszawa, Dialog. 406 p. 


\section{Information about the Author}

Aleksander Gadomski / Aleksandr Kazimirovich Gadomskiy, Doctor Habilitated of Arts in Linguistics (University of Warsaw, 2014), Doctor of Philological Sciences (A.A. Potebnia Institute of Linguistics of National Academy of Sciences of Ukraine, 2015), Professor, Head of Department of Belarusian Studies and Ukrainian Studies, Institute of Slavic Studies, Opole University, Copernicus Sq., 11, 45-060 Opole, Poland, akazsimf@mail.ru, akazsimf@wp.pl, https://orcid.org/0000-0003-4274-0966

\section{Информация об авторе}

Александр Казимирович Гадомский, доктор хабилитированный гуманитарных наук в области языкознания (Варшавский университет, 2014), доктор филологических наук (Институт языкознания им. А.А. Потебни Национальной Академии Наук Украины, 2015), профессор, заведующий кафедрой белорусских и украинских исследований, Институт славистики, Опольский университет, пл. Коперника, 11, 45-060 г. Ополе, Польша, akazsimf@mail.ru, akazsimf@wp.pl, https://orcid.org/00000003-4274-0966 